УДК [004.94+006.022]+[371.693.4+377.169.3]

DOI 10.36910/6775-2313-5352-2020-17-11

${ }^{1}$ A.I. Коробко, ${ }^{2}$ В.С. Шатіхіна

${ }^{1}$ Український науково-дослідний інститут прогнозування і випробування техніки i

технологій для сільськогосподврського виробництва імені Леоніда Погорілого, Харківська філія

${ }^{2}$ Харківський національний автомобільно-дорожній університет

\title{
ВІРТУАЛЬНИЙ ТРЕНАЖЕР АКРЕДИТОВАНОЇ ВИПРОБУВАЛЬНОЇ ЛАБОРАТОРІї
}

\begin{abstract}
Анотація. $B$ статті запропоновано конщепт віртуального тренажера випробувальної лабораторії призначеного для використання у навчальному прочесі при навчанні майбутніх фахівців випробувачів. Тренажер побудовано на принципах миследіяльністної методології: рівні ієрархії визначаються рівнем встановлених вимог, фази послідовністю впровадження нових редакцій нормативних документів, що регламентують діяльність випробувальної лабораторії, $і$ визначаються редакиією (версією) изих документів, види функиій визначають роль окремих елементів системи управління в загальній системі. Застосування запропонованого тренажера направлене на формування у студентів професійних знань, умінь $і$ навичків самостійно приймати рімення та формування індивідуальних рішень розв'язання ситуачій, здобуття надпрофесійних навичків (soft skills), здобуття професійних навиків роботи з нормативними документами (зокрема, стандартами), випробувальним устаткованням, засобами вимірювальної техніки, роботи з адміністрування систем управління якістю. При роботі з тренажером студенти самомотивуються для досягнення поставленої иілі иляхом усвідомлення важливості оптимального вирішення поставленої задачі.
\end{abstract}

Ключові слова: віртуальний тренажер, випробувальна лабораторія, система якості, технічні вимоги, метрологічне забезпечення, випробування, студенти.

Вступ. Для досягнення необхідних програмних результатів навчання і здобуття відповідних компетентностей під час навчання необхідно мати відповідну технічну базу, що дозволяє імітувати умови реальних виробничих ситуацій. Завершення 2019-2020 навчального року і продовження навчання у 2020-2021 навчальному році виявилося надто складним. Усі заклади освіти усіх рівнів змушені були перейти на дистанційну форму навчання. За відсутності чітких рекомендацій з боку органів управління закладами освіти, кожен 3 них змушений сам вибирати способи і засоби реалізації дистанційної форми навчання. Для проведення лекцій $є$ безліч on-line платформ. Тобто, це не викликає значних труднощів. Кожен викладач сам обирає найзручніші для нього способи комунікації зі студентами. Реалізація практичних і семінарських занять теж не викликає значних труднощів. Проблемним (особливо для технічних дисциплін) $є$ реалізація лабораторних робіт і проведення виробничих і переддипломних практик, проходження яких заплановано на діючих підприємствах реального сектору економіки.

В статті запропоновано концепт віртуального тренажера випробувальної лабораторії призначеного для використання у навчальному процесі при навчанні майбутніх фахівців випробувачів. Тренажер охоплює усі вимоги міжнародного стандарту ISO/IEC 17025-2017 [1] і направлений на здобуття практичних навичок розробки системи управління якістю, роботи у системі управління якістю та роботи у випробувальній лабораторії, в тому числі робіт 3 забезпечення і контролю якості випробувань, метрологічного забезпечення випробувальної лабораторії, тощо.

Питанню створення і розробки віртуальних тренажерів присвячено ряд робіт, як вітчизняних, так і закордонних авторів $[2,3,4,5,6]$.

Зокрема, в роботі [3] розглядається проектування тренажерів для підготовки операторів складних ергатичних систем, що працюють в умовах вітального стресу. Запропоновано методологію середовищеорієнтованого підходу до проектування навчальних середовищ, що використовує положення посткласичної ергономіки. Навчальне середовище представлене у виді аутопоетичної системи, що само організовується і включає оператора в якості активної конструкторської ланки.

(C) Коробко А. I., к.т.н, доц, Шатіхіна В. Є., студентка 
В роботі [4] формулюються основні напрямки розвитку інформаційно-освітнього середовища університету при навчанні плавскладу на базі розвитку розподіленої інфраструктури технічних і програмних комплексів, впровадження віртуальних тренажерів для моделювання умов квазіпрофесійної діяльності плавскладу. Обгрунтовується необхідність розвитку технологій e-learning для проведення практичних занять на реальному фізичному обладнанні.

В роботі [5] наводиться огляд сучасних підходів до формування адаптивних режимів в тренажерах операторів ергатичних систем. Показані обмеження класичної методології проектування адаптивних тренажерів, що використовують критерії адаптації за ефективністю виконання навчальних завдань. Запропоновано підходи до вибору способів адаптації, що враховують процеси самоорганізації навчального середовища. Актуальність даних досліджень підтверджується виникненням передпосилок до створення адаптивних тренажерних систем, в яких процес керування навчанням автоматизований [7]

Автор у [8] розглядає методологію проектування тренажерів, що містять штучні середовища діяльності. Розглянув детально проблеми математичного і педагогічного плану, що виникають при створенні проекту тренажера. Також показав особливості застосування теорії навчальних іммерсивних середовищ під час проектування тренажерів з віртуальними середовищами навчання.

Аналіз наведених і інших робіт показує, що на цей час відсутні роботи прикладного характеру, направлені на реалізацію побудови віртуальних тренажерів з підготовки фахівців у галузі випробувань, а саме майбутніх фахівців або керівників 3 якості випробувальних лабораторій.

Метою статті $\epsilon$ розробка концепту віртуального тренажера випробувальної лабораторії призначеного для використання у навчальному процесі при навчанні майбутніх фахівців випробувачів і розробка на його базі програмного забезпечення, що дає можливість реалізувати вимоги стандарту ISO/IEC 17025-2017 [1] у віртуальному середовищі.

Результати дослідження. Принципи побудови віртуальної лабораторії. Побудова «віртуальної лабораторії» здійснювалась з використанням миследіяльністної методології [9]. Вона може застосовуватися не тільки при організації технічних систем, тому вона узята як інструмент для проведення подальших досліджень в області управління якістю випробувань та розробки віртуальних тренажерів для навчання керуванню якістю.

Система за третім визначенням цього поняття має такі атрибути [9]:

- рівні ієрархії: підсистема, система, надсистема;

- фази: початкова (минула), основна (теперішня), заключна (майбутня);

- види функцій: допоміжна, основна, керівна.

Розповсюджуючи указане вище на систему управління якістю випробувань (система управління випробувальної лабораторії), пропонуються наступні атрибути (рис. 1).

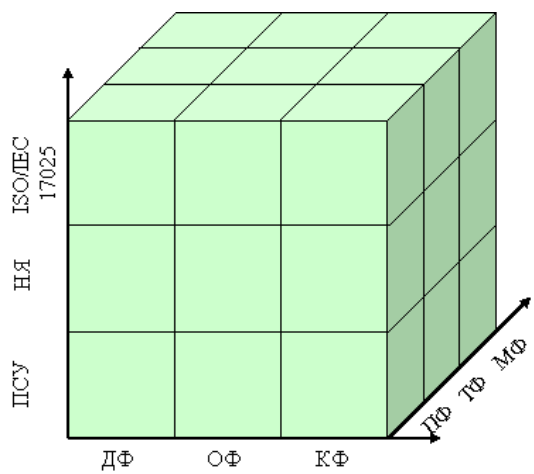

Рис. 1 Структура управління якістю, за третім визначенням поняття «система»

Рівні ієрархії визначаються рівнем встановлених вимог. Це: вимоги стандарту ISO/IEC 17025-2017 [1] - надсистема; вимоги Настанови 3 якості - система; вимоги процедур системи управління i форми підсистема. Найбільш узагальнено вимоги сформульовані у ISO/IEC 17025-2017 [1], далі вони деталізуються у Настанові з якості і повністю розкриваються у процедурах системи управління і формах.

Фази визначаються послідовністю впровадження нових редакцій нормативних документів, що регламентують діяльність випробувальної лабораторії, і визначаються редакцією (версією)цих документів. Початкова - версія системи управління, що розроблена і подана на акредитацію. Основна - версія, що реалізується в теперішній час. Майбутня версії, направлені на реалізацію постійного покращення (передбачувані вимоги).

Види функцій визначають роль окремих елементів системи управління в загальній системі. Основна функція - це випробування, тобто безпосереднє здійснення основної діяльності, що регламентується місією лабораторії. Допоміжна функція - передбачає 
забезпечення процесу випробувань необхідними умовами (кваліфікований персонал, правильні умови, валідовані і верифіковані методи випробувань, тощо). Керівна функція це контроль за діяльністю лабораторії через внутрішні аудити, аналізування з боку керівництва, керування невідповідною роботою, керування ризиками, тощо.

В залежності від встановлених вимог (ВВ) в період тієї чи іншої фази (Ф) (початкова фаза - ПФ, теперішня фаза - ТФ, майбутня фаза - МФ), основна функція (ОФ) реалізується із забезпеченням допоміжної функції (ДФ) і контролюється керівною функцією (КФ). На основі аналізу діяльності формуються передбачувані вимоги (ПВ). Отже, досягнутий результат (ДР) формується за наступною послідовністю

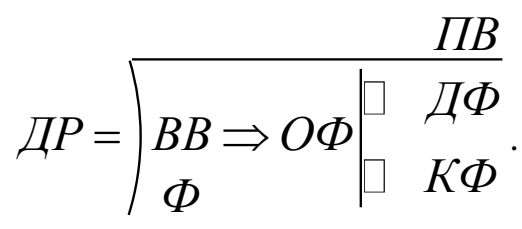

Синтез віртуального тренажера випробувальної лабораторії. У віртуальних тренажерах динаміка процесів реалізується за допомогою комп'ютерної анімації комплексу методів відображення будь-яких об'єктів в часі. Процеси формування понять за допомогою аналізу, порівняння, виділення істотних ознак і інших логічних операцій відтворюються фахівцем, які розробляють анімацію, в образній формі, і інтерактивно виводяться на дисплей комп'ютера в суворо визначеній послідовності [10]. Мультимедійна навчально-наукова лабораторія, як правило, поєднує в собі імітаційну динамічну модель обладнання і програмну оболонку, що включає методичний супровід лабораторної роботи. Саме за такими принципами побудовано модель віртуального тренажера випробувальної лабораторії (рис. 2). Основою побудови віртуальної випробувальної лабораторії є вимоги до iii структури, технічних даних (засоби вимірювальної техніки і випробувальне устатковання) та вимоги до системи якості.

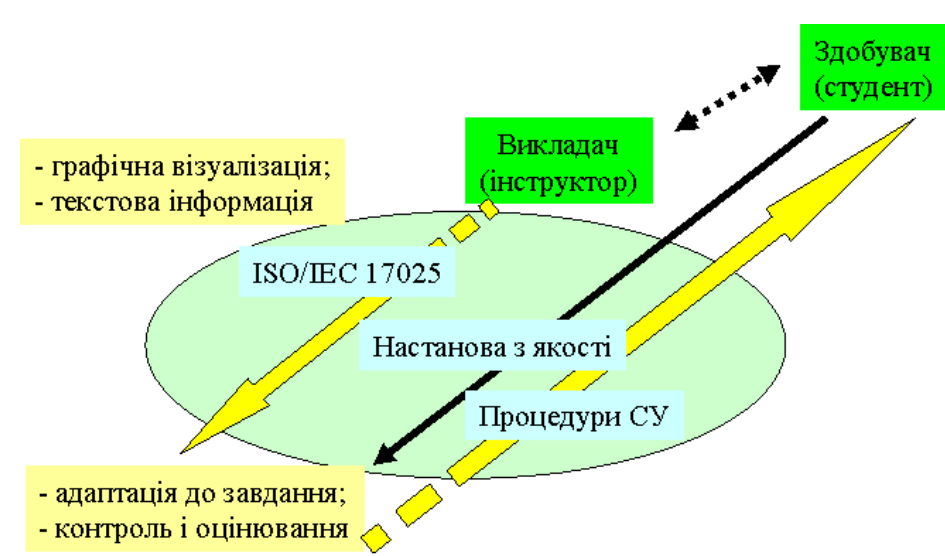

Рис. 2. Принципова схема віртуального тренажера випробувальної лабораторії

(в розрізі рівнів ієрархії)
Віртуальний тренажер випробувальної лабораторії являє собою програмний комплекс, що дозволяє відтворити i реалізовувати процеси управління діяльністю лабораторії без безпосереднього перебування у лабораторії. Він побудований за принципом конструюючої активності (орієнтований на середовище, посткласичний) [3] - оператор (здобувач) є активним діячем в середовищі, що реалізується тренажером. Активність суб'єкта формує його

когнітивні і операціональні структури, що сприяють досягненню певних програмних результатів навчання, які в свою чергу допомагають виконувати професійну діяльність.

Робота віртуального тренажера випробувальної лабораторії заключається у наступному. Викладач (інструктор) через інтерфейс формує завдання. Здобувач його виконує, причому тренажер реагує на дії здобувача і повідомляє йому про помилки, якщо такі виникають. Постійно іде обмін інформацією між викладачем і здобувачем. Викладач може надавати лише консультації і не може втручатись у роботу тренажера на етапі виконання завдання.

За рівнем складності завдання може бути:

- просте - виконується в розрізі одного рівня ієрархії (однієї фази, однієї функції); наприклад, скласти графік внутрішніх аудитів;

- середньої складності - виконується в розрізі комбінації рівнів ієрархії, фази або функції, причому одночасно використовується не більше трьох елементів; передбачає 
залучення додаткових джерел інформації; наприклад, розробити (актуалізувати) певну процедуру системи управління;

- складне - виконується в розрізі комбінації рівнів ієрархії, фази, функції (одночасно використовується чотири і більше елементів), передбачає залучення додаткових джерел інформації і направлене на посилену активізацію логічного мислення здобувача.

- контрольні - завдання, що виконується в розрізі одного рівня ієрархії (однієї фази, однієї функції); і направлені на вирішення питання: «Чому так?», можуть передбачати залучення додаткових джерел інформації;.

За функціональним призначенням завдання може бути: роботи);

- аналізування - аналіз певних ситуацій (практичні і семінарські заняття, лабораторні

- проектування - розробка певних проектних рішень системи управління (курсова робота, практика, дипломне проектування).

Характеристики основних компонент запропонованого віртуального тренажера наведено в табл. 1.

Таблиця 1

Аналіз запропонованої «віртуальної лабораторії» за ії функціональними показниками

\begin{tabular}{|c|c|}
\hline Компоненти & Опис характеристик \\
\hline $\begin{array}{ll}\text { Мета } & \text { системи } \\
\text { підготовки } & \end{array}$ & $\begin{array}{l}\text { Формування у студентів професійних знань, умінь і навиків. } \\
\text { Формування здатності самостійно приймати рішення та } \\
\text { формування індивідуальних рішень розв’ язання ситуацій. Здобуття } \\
\text { над професійних навичків (soft skills) }\end{array}$ \\
\hline Здобувач (студент) & $\begin{array}{l}\text { Студент самостійно приймає рішення щодо тієї чи іншої ситуації, з } \\
\text { розробкою пропозицій. Викладач лише консультує }\end{array}$ \\
\hline $\begin{array}{l}\text { Викладач } \\
\text { (інструктор) }\end{array}$ & 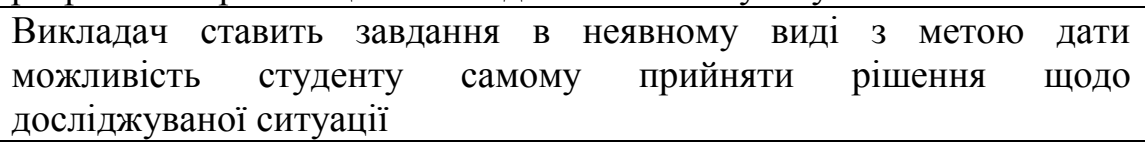 \\
\hline $\begin{array}{lr}\text { Роль } & \text { засобів } \\
\text { навчання } & \text { i } \\
\text { моделювання } & \\
\text { середовища навчання }\end{array}$ & $\begin{array}{l}\text { «Віртуальна лабораторія» передбачає формування ніш професійної } \\
\text { діяльності (керівник ВЛ, керівник з якості, тощо), крім цього } \\
\text { реалізуються професійні навики, що не пов'язані безпосередньо із } \\
\text { професійною діяльністю (soft skills) }\end{array}$ \\
\hline Зміст навчання & $\begin{array}{l}\text { Робота } 3 \text { «віртуальною лабораторією» передбачає освоєння повного } \\
\text { циклу роботи ВЛ }\end{array}$ \\
\hline Комунікації в системі & $\begin{array}{l}\text { Під час навчання студенти комунікують між собою і здатні } \\
\text { реагувати на ситуації, запропоновані іншими учасниками навчання }\end{array}$ \\
\hline Системи оцінок & $\begin{array}{l}\text { Простежуваність виконання завдання. Оцінки є інтегральними і } \\
\text { характеризують якість прийнятого рішення. Оцінки } \\
\text { класифікуються не за принципом «вірно }- \text { не вірно», а за } \\
\text { принципом «знайти оптимальне рішення» }\end{array}$ \\
\hline Роль оцінок & $\begin{array}{l}\text { Оцінки, отримані на проміжних етапах стимулюють до виконання } \\
\text { наступних завдань і покращення уже виконаних. }\end{array}$ \\
\hline $\begin{array}{l}\text { Організація системи } \\
\text { підготовки }\end{array}$ & $\begin{array}{l}\text { Навчальні завдання ставляться у кожному конкретному випадку. } \\
\text { Кожен студент має можливість вибрати свою системи організації } \\
\text { випробувальної лабораторії }\end{array}$ \\
\hline $\begin{array}{l}\text { Забезпечення } \\
\text { мотиваційної } \\
\text { діяльності }\end{array}$ & $\begin{array}{l}\text { Студенти самомотивуються для досягнення поставленої цілі } \\
\text { шляхом усвідомлення важливості оптимального вирішення } \\
\text { поставленої задачі }\end{array}$ \\
\hline $\begin{array}{l}\text { Форми взаємодії в } \\
\text { системі «середовище } \\
\text { - здобувач» }\end{array}$ & $\begin{array}{l}\text { Середовище навчання ставить задачі і студент реагує в залежності } \\
\text { від ситуації. Студенту дається право самостійно приймати рішення }\end{array}$ \\
\hline $\begin{array}{l}\text { Форма } \\
\text { представлення } \\
\text { навчального } \\
\text { матеріалу }\end{array}$ & 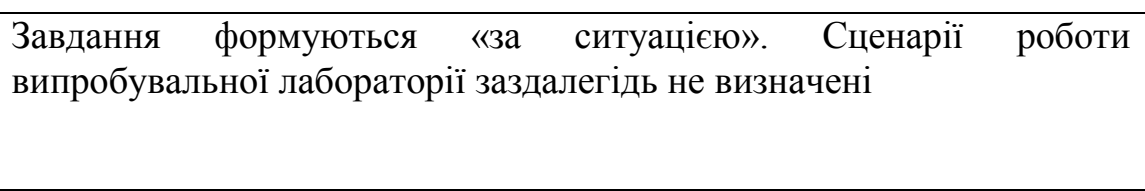 \\
\hline
\end{tabular}

(C) Коробко А. І., к.т.н, доц, Шатіхіна В. Є., студентка 
На сьогоднішній день програмний комплекс має назву «Laboratory test quality v.3 Virtual laboratory». Наразі він використовується під час навчання студентів за освітньою програмою «Професійна освіта. Метрологія, стандартизація та сертифікація».

Це віртуальна випробувальна лабораторія (що працює автономно без доступу до серверу), база даних якої наповнена (або наповнюється за завданням викладача) методами випробувань відповідно до діючих стандартів і з використанням інформації про сучасні засоби вимірювальної техніки і випробувальне устатковання, що використовуються при реалізації цих методів.

Віртуальна модель являє собою набір вікон програми, кожне з яких виконує певну функцію. Головне вікно програми показано на рис. 3.

Студенти мають можливість познайомитись з Паспортом та системою управління випробувальної лабораторії. В розділі «Паспорт» у зручному форматі можна переглянути усі форми паспорту ВЛ. При відкриванні певної форми, у вікні діалогу $\epsilon$ кнопки 3 перехрестними посиланнями на форми процедур системи управління. Так, наприклад, при перегляді інформації про певне випробувальне устатковання (ВУ) або засіб вимірювальної техніки (ЗВТ) форми 3 або форми 4 Паспорту,відповідно, можна переглянути інформацію про персонал, що уповноважений працювати 3 цим устаткованням. Аналогічно працюють $\mathrm{i}$ форми перегляду нормативних документів на продукцію (форма 2.1) чи на методи випробувань (форма 2.2). Переглядаючи форму 2.2 можна переглянути інформацію стосовно того, хто із працівників уповноважений на проведення конкретного методу, яке ВУ і ЗВТ використовується, тощо.

Система управління ВЛ працює в інтерактивному режимі. Студенти мають змогу виконувати завдання, що ставить викладач. Наприклад, скласти програму калібрування ЗВТ, графік технічного обслуговування ЗВТ і ВУ, тощо. Студенти навчаються проводити внутрішні аудити, починаючи зі складання графіку аудитів на рік, програми кожного аудиту, складати опитувальні листи і т. д. до завершення аудиту, розробки коригувальних дій i відслідковування їх виконання з оцінкою ефективності.

При «роботі з замовником» студенти навчаються аналізувати заявку на випробування, формувати програму випробувань, засвоюють принципи ідентифікації і відбору зразків, тощо.

Вибравши з бази даних за завданням викладача вид продукції, випробування якої проводить лабораторія і мету іï випробувань, студенти визначать нормативні документи на вимоги до неї, визначають можливі методи випробувань щодо неї, необхідні ЗВТ і ВУ, призначають випробувачів, що уповноважені на виконання відповідних робіт.

Передбачено також можливість конструювання (удосконалення) студентами інтерфейсу тренажера. Такі роботи виконуються в межах освітнього компоненту «Інформаційні технології в сфері стандартизації».

Форми роботи з тренажером наступні:

- уся група студентів діє як одна лабораторія із розподілом повноважень між студентами відповідно до віртуальних посад;

- кожному студенту дається індивідуальне завдання.

Викладач формує завдання кожному студенту відповідно до вибраного способу. В подальшому, файли створені студентами в поточному році можуть використовуватись як відправна точка для формування завдання студентам наступних років. Завдання може заключатись у розвитку бази даних, наповнення ії новими засобами вимірювальної техніки, формування програм калібрування, пошуку невідповідностей у системі управління, тощо та модернізації самого програмного комплексу.

\section{Висновки:}

Миследіяльністна методологія $€$ ефективним інструментом побудови систем управління якістю. Рівні ієрархії визначаються рівнем встановлених вимог. Фази визначаються послідовністю впровадження нових редакцій нормативних документів, що регламентують діяльність випробувальної лабораторії, і визначаються редакцією (версією) цих документів. Види функцій визначають роль окремих елементів системи управління в загальній системі. Основою побудови віртуальної випробувальної лабораторії $\epsilon$ вимоги до ії структури, технічних даних (засоби вимірювальної техніки і випробувальне устатковання) та вимоги до системи якості 
Запропонований віртуальний тренажер випробувальної лабораторії призначений для використання у навчальному процесі при навчанні майбутніх фахівців випробувачів. Його застосування направлене на формування у студентів професійних знань, умінь і навичків самостійно приймати рішення та формування індивідуальних рішень розв'язання ситуацій, здобуття надпрофесійних навичків (soft skills), здобуття професійних навиків роботи 3 нормативними документами (зокрема, стандартами), випробувальним устаткованням, засобами вимірювальної техніки, роботи з адміністрування систем управління якістю. При роботі з тренажером студенти самомотивуються для досягнення поставленої цілі шляхом усвідомлення важливості оптимального вирішення поставленої задачі.

\section{Список використаних джерел}

1. ISO/IEC 17025:2017 General requirements for the competence of testing and calibration laboratories. Acting on 2018-01-01.

2. Норенков И. П., Зимин А. М. Информационные технологии в образовании. М. : Изд-во МГТУ им. Н.Э. Баумана, 2004. 352 с.

3. Сергеев С. Ф. Методология проектирования тренажеров с иммерсивными обучающими средами. Научно-технический вестник Санкт-Петербургского государственного университета информационных технологий, механики и оптики. 2011, № 1 (71). C. 109-114.

4. Фомина И. К., Тарануха С. Н. Виртуальные тренажеры при дистанционном обучении плавсостава. Интерактивная наука. 2017. Вып. 11. С. 145-148.

5. Сергеев С. Ф. Адаптивность в тренажерах. Научно-технический вестник СанктПетербургского государственного университета информационных технологий, механики и оптики, 2011, № 6 (76). С. 118-123.

6. Среда программно-технических комплексов по лабораторным практикумам удаленного доступа (e-Learning Labs Technologies: e-LLT) / П.Ф. Баранов, С.А. Горисев, И.В. Ряшенцев. Уровневая подготовка специалистов: государственные и международные стандарты инженерного образования: Сб. трудов научно-методической конференции. Томск, 2011. C. $167-169$.

7. Соколов В. Н. Адаптивные тренажерные системы: проектирование и оценка. СПб : Изд-во Политехн. ун-та, 2011. 160 с.

8. Сергеев С.Ф. Виртуальные тренажеры: проблемы теории и методологии проектирования. Человеко-машинные системы. 2010. № 2 (8). С. 15-20.

9. Структура системомыследеятельностного комплекса для моделирования транспортных систем / Н. Э. Тернюк и др. Механіка та машинобудування. 2011. № 1. С. 141-148.

10. Процесс обучения с применением виртуального тренажера [https://www.sunspire.ru/articles/part34/]. Дата звернення 31.10.2020.

\section{${ }^{1}$ А.И. Коробко, ${ }^{2}$ В.Е. Шатихина \\ ${ }^{1}$ Украинский научно-исследовательский институт прогнозирования и испытаний техники и технологий для сельскохозяйственного производства имени Леонида Погорелого, Харьковский филиал \\ ${ }^{2}$ Харьковский национальный автомобильно-дорожный университет \\ ВИРТУАЛЬНЫЙ ТРЕНАЖЕР АККРЕДИТОВАННОЙ ИСПЫТАТЕЛЬНОЙ ЛАБОРАТОРИИ}

В статье предложен концепт виртуального тренажера испьтательной лаборатории предназначенного для использования в учебном прочессе при обучении будущих специалистов-испытателей. Тренажер построен на принципах мыследеятельностной методологии: уровни иерархии определяются уровнем установленньх требований, фазы последовательностью внедрения новых редакций нормативных документов, регламентируюших деятельность испьтательной лаборатории, и определяются редакцией (версией) этих документов, виды функиий определяют роль отдельных элементов системь управления в общей системе. Использование предложенного тренажера направлено на формирование у студентов профессиональных знаний, умений и навыков самостоятельно 
принимать решения и формирование индивидуальных решений ситуаций, получение сверхпрофессиональных навыков (soft skills), получение профессиональных навыков работы с нормативными документами (в частности, стандартами), испытательным оборудованием, средствами измерительной техники, работь по администрированию систем управления качеством. При работе с тренажером студенты самомотивируются для достижения поставленной иели путем осознания важности оптимального решения поставленной задачи.

Ключевые слова: виртуальный тренажер, испытательная лаборатория, система качества, технические требования, метрологическое обеспечение, испытания, студенты

\author{
${ }^{1}$ A. Korobko, ${ }^{2}$ V. Shatihina

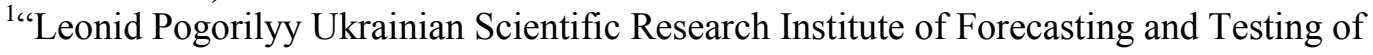 \\ Machinery and Technologies for Agricultural Production", Kharkiv branch \\ ${ }^{2}$ Kharkiv national automobile and highway University
}

\title{
VIRTUAL SIMULATOR FOR TEST LABORATORY ACCREDITED
}

The article proposes a concept of a virtual simulator for a testing laboratory. The virtual simulator is intended for use in the educational process during the training of test specialists. The simulator is built on the principles of thought-activity methodology. The levels of the hierarchy are determined by the level of established requirements. The phases are determined by the sequence of implementation of new editions of normative documents. These documents regulate the activities of the testing laboratory. The types of functions determine the role of individual elements of the control system in the overall system. The use of the simulator forms students' professional knowledge, abilities and skills for independent decision-making. Forms individual solutions to situations. Forms soft skills. Forms professional skills for working with standards, test equipment, measuring instruments, administration of quality management systems. Students are self-motivated, achieve the set goal, and realize the importance of the optimal solution to the task.

Keywords: virtual simulator, testing laboratory, quality system, technical requirements, metrological support, testing, students. 